\section{PETITION FOR SUBSIDISED TUITION FOR FUTURE SURGEONS}

A petition has been set up to protest the lack of funding available for students studying dentistry secondary to medicine, or vice versa.

Dental student Hannah BarhamBrown (pictured) alerted the $B D J$ to a posting entitled Building faces while demolishing my bank balance... on her blog (http://tinyurl.com/qygso7w). In it she writes that dentistry is her third medical degree on the path to becoming a maxfax surgeon and says: :...the funding for students doing dentistry secondary to medicine (or vice versa) is less than negligible; there is currently no student finance tuition fee loan. This means I have to magic up $£ 36,000$ which will need to be paid AS I G0'. She points out that maxfax surgeons are in greater demand than ever before but that applicants are being priced out of the specialty.
ENT surgeon Dr Miran Pankhania has set up the petition for subsidised tuition fees for medical and dental graduates pursuing a career in maxillofacial surgery at http://epetitions.direct.gov.uk/ petitions/69672 to

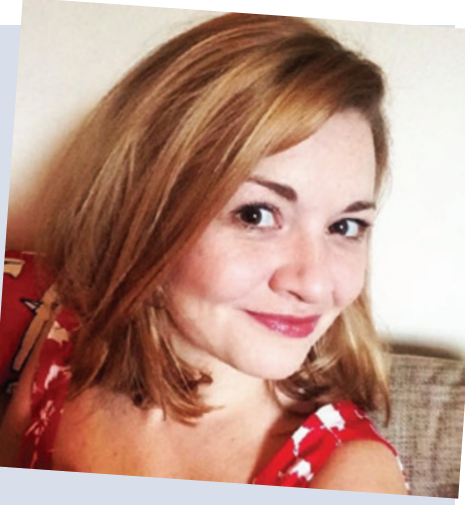

help out his future colleagues and Hannah hopes that $B D J$ readers will support their cause.

\title{
ELECTIONS TO THE BDA COUNTRY COUNCILS
}

Nominations are sought for seats on the following Country Councils of the British Dental Association: England, Northern Ireland, Scotland and Wales.

Each Country Council has the following remit:

- To provide regular advice and comment to the Principal Executive Committee (PEC) as consultative committees

- To consider and advise the PEC on all matters relating to dentistry within the country concerned

- To advise the PEC on all aspects of policy within the country concerned, facilitating external expert and member input to policy formation where required

- To receive regular reports from the PEC, to enable each country council to debate and comment on the activities of the PEC

- To liaise with branches and sections.

Members are elected from the branches in each country or, in the case of Wales, sections.

The Country Councils play a vital role in ensuring that the PEC, which is concerned with the strategic direction and governance of the Association, is kept in touch with the views and concerns of members. Country Council members are the 'voice of members' to the PEC and senior management team.

The Country Councils together constitute the United Kingdom Council which, amongst other functions, considers an annual report from the PEC on its strategic priorities and activities.

Term of office

This shall be until February 2018, with the entitlement to stand for a further three year term of office at that point.

More information about the elections to the Country Councils and other BDA elections, including downloadable nomination forms, can be found at: bda.org/elections

Nomination forms must be returned to the Elections Team at 64 Wimpole Street London W1G 8YS or elections@bda.org by 17.00 Friday 16 January 2015.

Hard copy election packs can also be obtained by contacting Stephen Skelton on 02075634141 or emailing s.skelton@bda.org.

\section{ENHANCED ORAL CARE LOWERS INFECTION RISK IN ICU}

Patients in an intensive care unit who received enhanced oral care from a dentist were at significantly less risk for developing a lower respiratory tract infection. ${ }^{1}$
1. Bellissimo-Rodrigues W T, Menequeti M $G$, Gaspar $\mathrm{G} G$ et al. Effectiveness of a dental care intervention in the prevention of lower respiratory tract nosocomial infections among intensive care patients: a randomized clinical trial. Infect Control Hosp Epidemio/ 2014; 35: 1342-1348.

\section{PHOTO STORY}

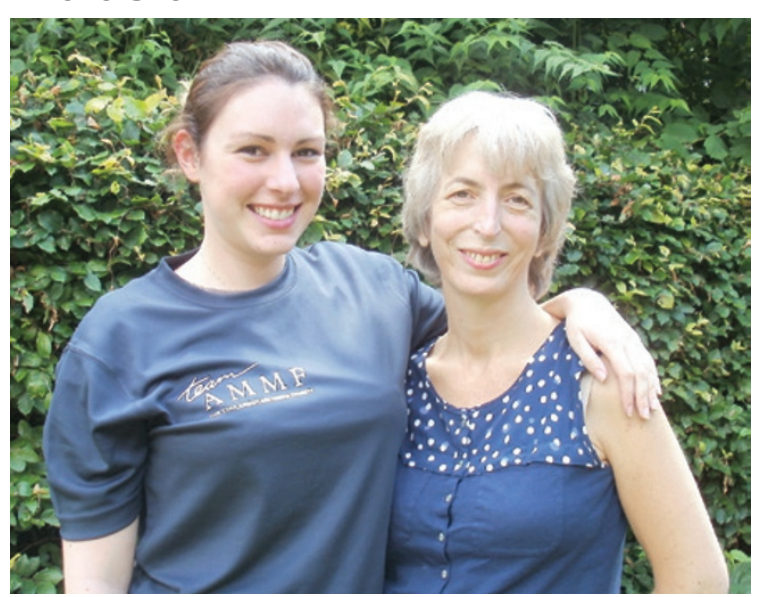

Sarah Smith (left) has raised over $£ 4,600$ for AMMF, a charity aiming to raise awareness of cholangiocarcinoma (bile duct cancer), by climbing Mount Kilimanjaro, in support of colleague Kathryn Swain (right). Kathryn worked as an associate dentist in Macclesfield for 25 years and in March 2013 was diagnosed out of the blue with cholangiocarcinoma. Sarah originally joined Kathryn's practice as a trainee dental nurse and later left to train as a dental therapist. Wanting to do something positive to support long-time friend and colleague Kathryn, she decided to climb Kili, paying all her own expenses, and has been sponsored by patients, colleagues and friends well beyond her target of $£ 2,500$.

\section{VETS DREAD FELINE DENTAL PROCEDURES}

Over half of final year veterinary students in the UK do not feel confident either in discussing orodental problems with clients or in performing a detailed examination of the oral cavity of their small animal patients. ${ }^{1}$ Once in practice, things don't always improve and, anecdotally, it seems many vets dread feline dental procedures. Two guest editors of the Journal of Feline Medicine and Surgery harnessed their passion for cats and the expertise they have developed in small animal dentistry to produce a two-part special issue devoted to feline dentistry.

1. Perry R. Final year veterinary students' attitudes towards small animal dentistry: a questionnaire-based survey. J Small Anim Pract 2014; 55: 457-464. 